\title{
РОЗРОБЛЕННЯ СТРАТЕГІЇ ЗАБЕЗПЕЧЕННЯ ЕКОНОМІЧНОЇ БЕЗПЕКИ ПІДПРИЄМСТВ ЕНЕРГЕТИЧНОЇ ГАЛУЗІ
}

\author{
РАЗРАБОТКА СТРАТЕГИИ ОБЕСПЕЧЕНИЯ ЭКОНОМИЧЕСКОЙ \\ БЕЗОПАСНОСТИ ПРЕДПРИЯТИЙ ЭНЕРГЕТИЧЕСКОЙ ОТРАСЛИ
DEVELOPING THE STRATEGY OF ECONOMIC SECURITY OF ENERGY COMPANIES

\begin{abstract}
Проблема розроблення стратегї забезпечення економічної безпеки підприємств енергетичної галузі є надзвичайно актуальною, щзо викликає необхідність ї̈ комплексного вирішення з урахуванням сучасних тенденцій розвитку підприємств, використання нових технологій та проблем, викликаних кризовими станами, щуо наразі існують. У статті пропонується власне бачення вимог, яким має відповідати процес розроблення стратегії забезпечення економічної безпеки підприємств, а саме : існування обмежень, зумовлених рівнем економічної безпеки підприємства, проявами зовнішнього середовища; адекватність стратегії забезпечення економічної безпеки підприємства економічній ситуачії в країні; відповідність стратегії забезпечення економічної безпеки загальній стратегії безпеки країни; альтернативність вибору стратегії. Показано місие стратегї забезпечення економічної безпеки $i$ ієрархї стратегій енергетичного підприємства. Запропоновано виділяти стратегї забезпечення економічної безпеки підприємств енергетичної галузі залежно від зон (рівня) економічної безпеки. Для розроблення стратегії забезпечення економічної безпеки підприємств енергетичної галузі визначено алгоритм та інструментарій формування такої стратегії.
\end{abstract}

Ключові слова : стратегія, економічна безпека, забезпечення.

Проблема разработки стратегии обеспечения экономической безопасности предприятий энергетической отрасли является чрезвычайно актуальной, что вызывает необходимость ее комплексного решения с учетом современных тенденций развития предприятий, использования новых технологий и проблем, вызванных кризисными состояниями, которые на данный момент существуют. В статье предлагается свое видение требований, которым должен соответствовать процесс разработки стратегии обеспечения экономической безопасности предприятий, а именно : существование ограничений, обусловленных уровнем экономической безопасности предприятия, проявлениями внешней среды; адекватность стратегии обеспечения экономической безопасности предприятия экономической ситуаџии в стране; соответствие стратегии обеспечения экономической безопасности общей стратегии безопасности страны; альтернативность выбора стратегии. Показано место стратегии обеспечения экономической безопасности и иерархии стратегий энергетического предприятия. Предложено выделять стратегии обеспечения экономической безопасности предприятий энергетической отрасли в зависимости от зон (уровня) экономической безопасности. Для разработки стратегии обеспечения экономической безопасности предприятий 
энергетической отрасли определен алгоритм и инструментарий формирования такой стратегии.

Ключевые слова : стратегия, экономическая безопасность, обеспечения.

The problem of the development strategy for the economic security of enterprises energy sector is extremely important that it necessitates an integrated solution with current business trends, the use of new technologies and problems caused by crisis conditions that currently exist. The article offers own vision requirements to be met by the process of developing a strategy to ensure economic security, namely the existence of restrictions caused by the level of economic security, environmental displays; adequacy strategy for economic security economic situation in the country; compliance strategy to ensure economic security overall security strategy; alternative selection strategy. The place strategies to ensure economic security and energy strategies of the company hierarchy. A highlight economic security strategy for the energy sector enterprises depending on the zone (level) economic security. To develop a strategy for ensuring the economic security of the energy sector enterprises defined algorithm and forming tools of this strategy.

Keywords: strategy, economic security, insurance.

Вступ. Питання забезпечення високого рівня економічної безпеки підприємств досліджувалися багатьма вченими як в Україні, так і за кордоном, що підтверджує актуальність даної сфери дослідження. Вагомий внесок у розвиток теоретичних засад економічної безпеки підприємства внесли С. М. Ілляшенко, Г. В. Козаченко, В. П. Пономарьова, О. М. Ляшенко, А. І. Сухорукова, С. В. Кавун, С. М. Шкарлет, Л. О. Корчевська. В. І. Ящук та ін. Питанням стратегічного розвитку підприємств присвячені праці О. А. Гавриша, С. В. Войтко, В. Г. Герасимчука, В. В. Дергачової, О. О. Охріменко, Л. М. Шульгіної.

Разом 3 тим, неповною мірою розглянуті питання розроблення стратегії забезпечення економічної безпеки енергетичних підприємств, що зумовлює актуальність наукових досліджень у даній сфері.

Постановка завдання. Основними завданнями даного дослідження $є$ : аналіз теоретичних підходів до стратегії забезпечення економічної безпеки підприємства; виокремлення основних етапів процесу розроблення та реалізації стратегії забезпечення економічної безпеки енергетичного підприємства; визначення алгоритму та інструментарію формування такої стратегіï.

Методологія дослідження. Для досягнення поставленої мети було використано наступні методи дослідження : графічний - для наочного відображення процесу розроблення стратегії забезпечення економічної безпеки підприємств енергетичної галузі, визначення стратегій залежно від зон економічної безпеки; аналізу - для визначення місця стратегії забезпечення економічної безпеки в загальній ієрархії стратегій підприємства; теоретичне узагальнення - для обгрунтування переліку стратегій забезпечення економічної безпеки. 
Результати дослідження. Ключовим моментом подальшого розвитку відносин Україна - СС в енергетичній сфері $\epsilon$ трансформація моделі енергетичного ринку, виникнення конкуренції між вітчизняними виробниками електроенергії, що спричинить загрози, але разом з тим, містить численні можливості успішного розвитку енергетичної галузі України. У сучасних умовах реформування ринку електроенергетики успішність та ефективність роботи енергетичних підприємств, зокрема, теплоелектростанцій (ТЕС), залежить від правильно обраної стратегії. За роками будівництва більшість ТЕС побудовані у 70-80 pр. минулого століття, відповідно існує потреба в їх оновленні та реконструкції, оскільки подальша експлуатація несе значні ризики виникнення техногенних аварій, проблем з постачанням електроенергії населенню та неконтрольованого збільшення собівартості електроенергії.

За встановленою потужністю переважають енергогенеруючі підприємства ПАТ «ДТЕК Дніпроенерго» та ПАТ «Центренерго», що обумовлено кількістю енергоблоків - відповідно 25 блоків і 23 блоки. При цьому використання встановленої потужності на ТЕС України є низьким лише третина потужностей використовується.

На сьогодні загальноприйнятого стандарту щодо змісту стратегії та іiі структури не існує, що пояснюється складністю та багатоплановістю трактування даної категорії.

Забезпечення економічної безпеки енергетичного підприємства потребує розроблення відповідного інструментарію, який надасть можливість підприємству досягти достатнього рівня безпеки в умовах нестабільного ринкового середовища, поставлених стратегічних цілей і переваг на ринку енергетики. Необхідною складовою успішності підприємства $є$ прийняття правильних управлінських рішень як на тактичному, так і на стратегічному горизонті діяльності, з огляду на що постає завдання у розробленні стратегій забезпечення економічної безпеки як частини загальної стратегії енергетичного підприємства.

Концептуально поняття «стратегії» в економічній літературі трактують як :

- мету управління (ідеальну модель підприємства, в якій реалізується бачення його керівників, власників); позицію на ринках (передусім конкурентну участь на ринках, захоплення нових ринків); зразок (джерело прагнення підприємства наблизитися до еталона);

- запланований майбутній результат, напрям розвитку, перспективне уявлення про майбутній стан підприємства, маневр у конкурентній боротьбі;

- визначення основних довгострокових цілей і завдань, ухвалення курсу дій, розподілу ресурсів, необхідних для виконання поставлених завдань;

- загальний всебічний план досягнення цілей; 
- довгостроковий курс розвитку підприємства, спосіб досягнення цілей;

- комплекс прийнятих рішень стосовно розміщення ресурсів і досягнення довгострокових конкурентних переваг на цільових ринках;

- узагальнену програму діяльності, спрямовану на досягнення підприємством мети завдяки ефективному розподілу, координації та використанню ресурсів [1, с. 215].

На сьогодні теоретико - методичне забезпечення стосовно стратегій економічної безпеки підприємства залишається недостатньо обгрунтованим через відсутність грунтовних підходів до класифікації стратегій економічної безпеки. Зокрема, Т. Іванюта та О. Заїчковський пропонують лише три типи стратегії економічної безпеки підприємства: 1) раптового реагування на загрози; 2) прогнозування небезпек та загроз; 3) відшкодування завданих збитків [2].

У той же час П. Кравчук пропонує використовувати підхід, згідно 3 яким для забезпечення економічної безпеки підприємства слід користуватися трьома стратегіями: договірною, матричною, комплексною. Головними критеріями диференціації стратегічних підходів до управління фінансовоекономічною безпекою підприємства $\epsilon$ такі чинники: 1) стан фінансовоекономічної безпеки суб'єкта господарювання на момент розробки (коригування) стратегій; 2) фінансові можливості підприємства щодо політики безпеки [3].

Залежно від рівня безпеки підприємства та його фінансових можливостей група авторів Васильців Т. Г., Волошин В. І., Бойкевич О. Р., Каркавчук В. В. виділяють такі види стратегій забезпечення економічної безпеки: системного планового забезпечення; швидкого реагування; інституціоналізації та послідовного зміцнення; комплексного гарантування; відшкодування збитку; раптового реагування; сегментованого забезпечення; часткового врахування; делегування функцій [1, с. 220].

Отже, проаналізувавши існуючі погляди та наукові підходи, на нашу думку, стратегії забезпечення економічної безпеки можна умовно розділити на дві групи:

1. Стратегії підтримання економічної безпеки (нівелювання існуючих загроз, превенції загрозам, компенсації збитку).

2. Стратегії відновлення економічної безпеки (збільшення прибутків, зниження витрат, продажу активів, комплексна стратегія відновлення).

Загальна стратегія енергетичного підприємства має ієрархічну будову, включаючи бізнес-стратегії та функціональні стратегії, розроблення яких покладається на функціональні відділи підприємства (рис. 1). Якщо загальна стратегія установлює генеральний напрямок розвитку підприємства, то конкурентна стратегія детально регламентує досягнення стійких переваг перед конкурентами та частку кожного структурного підрозділу у розв'язання 
завдань підприємства в цілому. На рівні такого структурного утворення як відділ економічної безпеки керівництвом вирішуються питання пошуку ефективної стратегії у рамках загальної стратегії, яка б концентрувалася на захисті від загроз зовнішнього та внутрішнього середовища підприємства, підвищенні рівня економічної безпеки, підтримуючих стратегіях.

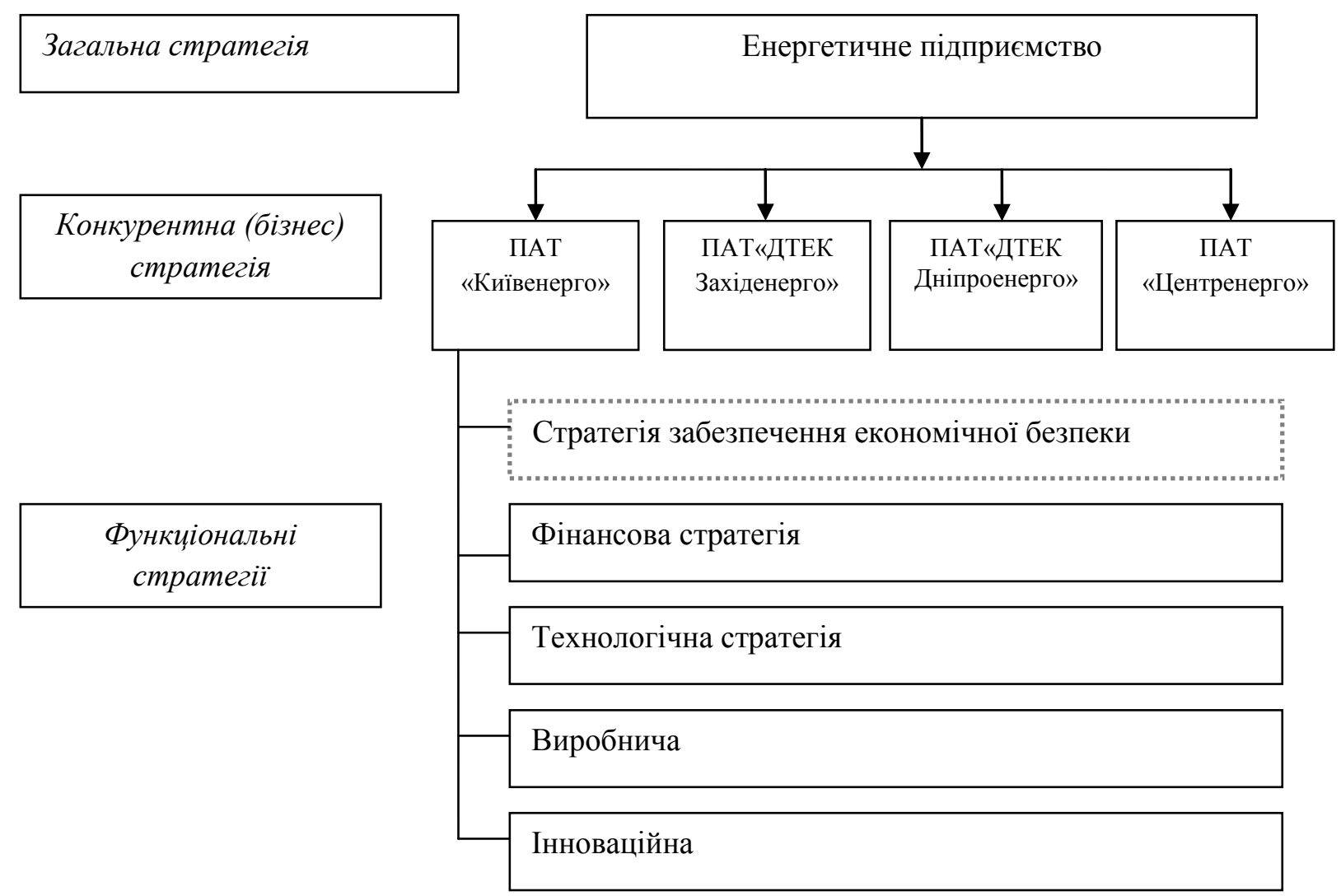

Рис. 1. Місце стратегії забезпечення економічної безпеки і ієрархії стратегій енергетичного підприємства (запропоновано авторами)

Розроблення стратегії забезпечення економічної безпеки підприємства за своєю суттю є елементом стратегічного управління, тобто, як вважають 3. Шершньова та С. Оборська - багатопланового, формально-поведінкового управлінського процесу, який допомагає формулювати та виконувати ефективні стратегії, що сприяють балансуванню відносин між організацією, включаючи ії окремі частини, та зовнішнім середовищем, а також досягненню встановлених цілей [4]. Це процес, за допомогою якого апарат управління підприємством здійснює довгострокове керівництво підприємством, визначає цілі діяльності, розробляе стратегію їх досягнення, враховуючи всі релевантні (найсуттєвіші) зовнішні та внутрішні умови, а також забезпечує виконання розроблених відповідних планів, постійно розвиваючись і змінюючись [5].

Процес розроблення стратегій забезпечення економічної безпеки може відбуватися двома шляхами: 
1) “Зверху-вниз”, при якому керівництво підприємства ініціює процес розроблення стратегій і уповноважують відділ економічної безпеки на розроблення стратегії з подальшим ії̈ погодженням;

2) “Знизу-вверх”, при якому процес розроблення стратегії забезпечення економічної безпеки ініціюється структурним підрозділом, який відповідає за забезпечення економічної безпеки.

На етапі формування стратегічних напрямів забезпечення економічної безпеки, тактики та логіки процесу прийняття рішень нами пропонується визначати такі зони економічної безпеки підприємств енергетичної галузі та відповідні їм стратегії забезпечення економічної безпеки з присвоєнням кожній стратегії ідентифікатора (S) на основі попередньо проведеного на підприємстві аналізу рівня економічної безпеки (рис. 2).

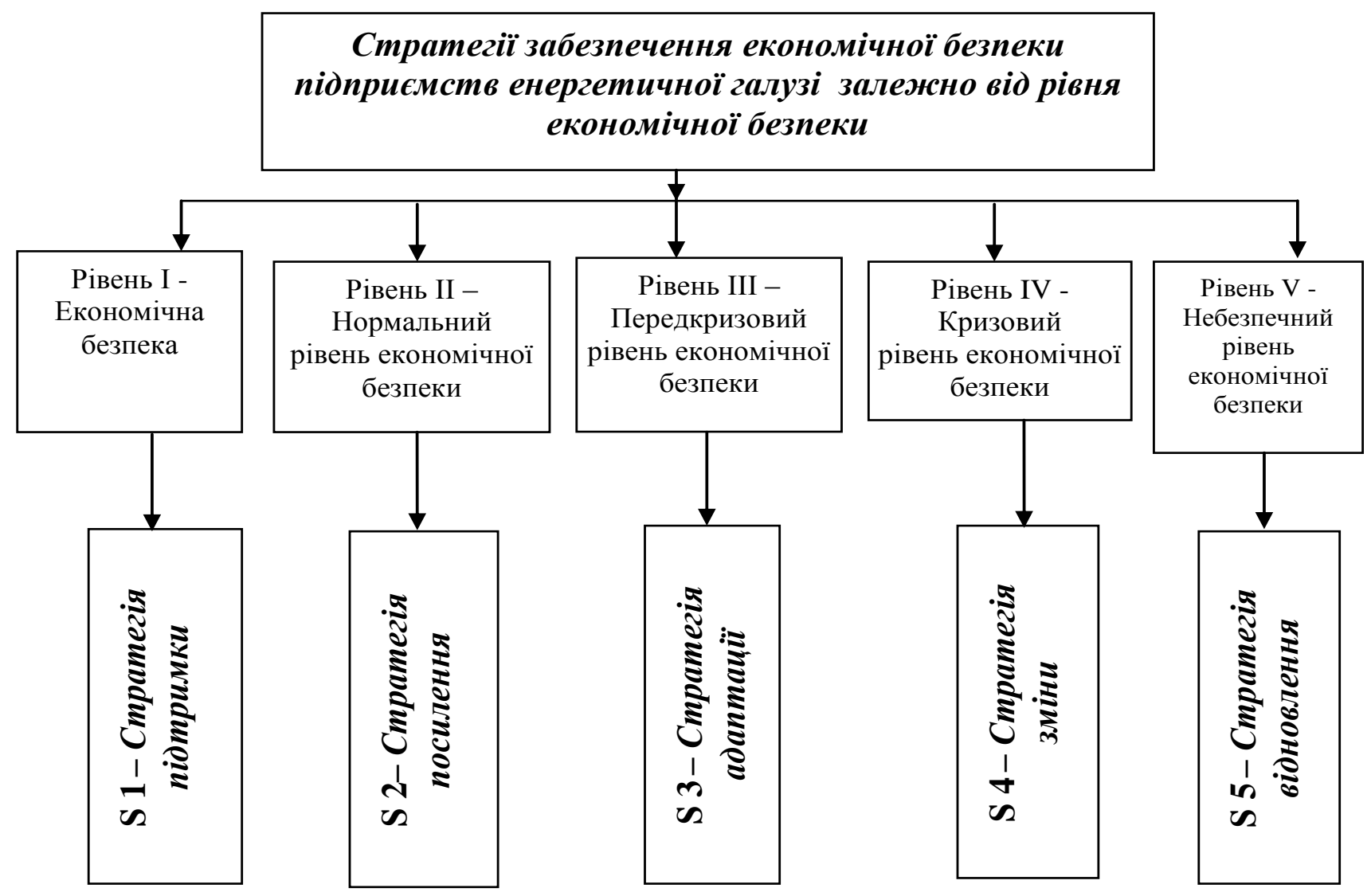

Рис. 2. Стратегії забезпечення економічної безпеки підприємств енергетичної галузі залежно від рівня економічної безпеки (запропоновано авторами)

Автором виділено п'ять основних стратегій забезпечення економічної безпеки підприємств енергетичної галузі, а саме:

- Стратегія зростання - передбачає збереження досягнутого рівня економічної безпеки, контроль за результатами діяльності та попередження виникнення можливих загроз економічним інтересам енергетичного підприємства. 
- Вибірково-посилююча стратегія - спрямована на проведення заходів посилення одного із показників компонент економічної безпеки енергетичного підприємства.

- Пристосувальна стратегія - направлена на проведення заходів пристосування компонент економічної безпеки енергетичних підприємств до змін зовнішнього середовища.

- Трансформаційна стратегія - передбачає проведення змін, які стосуються виду діяльності, трансформації ринку, а також проведенні необхідних змін компонент економічної безпекиенергетичних підприємств.

- Комплексно-убезпечуюча стратегія - спрямована на проведення заходів, направлених на досягнення рівня економічної безпеки, бажаного для підприємства.

у таблиці наведено характеристику запропонованих стратегій у залежності від рівня економічної безпеки енергетичних підприємств.

Таблиця

\section{Стратегії забезпечення економічної безпеки енергетичних підприсмств залежно від рівня економічної безпеки}

\begin{tabular}{|c|c|c|c|}
\hline $\begin{array}{c}\text { Рівнь } \\
\text { економічної } \\
\text { безпеки }\end{array}$ & $\begin{array}{c}\text { Характеристика рівня } \\
\text { економічної безпеки }\end{array}$ & $\begin{array}{c}\text { Стратегія } \\
\text { забезпечення } \\
\text { економічної безпеки }\end{array}$ & Характеристика стратегії \\
\hline $\begin{array}{l}\text { I. Економічна } \\
\text { безпека } \\
0,95 \leq \mathrm{P} \leq 1\end{array}$ & $\begin{array}{c}\text { Рівнем "економічна безпека" } \\
\epsilon \text { таке функціонування } \\
\text { енергетичного підприємства, } \\
\text { що передбачає ефективне } \\
\text { здійснення функцій } \\
\text { підприємства, наявність } \\
\text { надійної системи } \\
\text { забезпечення економічної } \\
\text { безпеки, яка надає } \\
\text { можливість управляти ії } \\
\text { функціональними } \\
\text { компонентами. }\end{array}$ & Стратегія зростання & $\begin{array}{c}\text { Передбачає збереження } \\
\text { достатнього рівня } \\
\text { економічної безпеки, } \\
\text { контроль за результатами } \\
\text { діяльності та попередження } \\
\text { виникнення можливих } \\
\text { загроз економічним } \\
\text { інтересам підприємства }\end{array}$ \\
\hline $\begin{array}{l}\text { II. Нормальний } \\
0,75 \leq \mathrm{P}<0,95\end{array}$ & $\begin{array}{c}\text { Нормальний рівень } \\
\text { економічної безпеки } \\
\text { передбачає прибутковість } \\
\text { підприємства із } \\
\text { послабленням однієї або } \\
\text { декількох компонент } \\
\text { економічної безпеки. }\end{array}$ & $\begin{array}{c}\text { Вибірково- } \\
\text { посилююча } \\
\text { стратегія }\end{array}$ & $\begin{array}{c}\text { Передбачає проведення } \\
\text { заходів посилення однієї з } \\
\text { компонент економічної } \\
\text { безпеки підприємства, } \\
\text { значення якого є } \\
\text { недостатнім }\end{array}$ \\
\hline $\begin{array}{l}\text { III. Передкризовий } \\
0,5 \leq \mathrm{P}<0,75\end{array}$ & $\begin{array}{c}\text { Передкризовим є такий } \\
\text { рівень економічної безпеки, } \\
\text { при якому фінансово- } \\
\text { господарська діяльність } \\
\text { суб’єкта господарювання } \\
\text { неспроможна забезпечити } \\
\text { належні обсяги доходу та є } \\
\text { збитковою. }\end{array}$ & $\begin{array}{c}\text { Пристосувальна } \\
\text { стратегія }\end{array}$ & $\begin{array}{c}\text { Передбачає проведення } \\
\text { заходів пристосування виду } \\
\text { діяльності до змін } \\
\text { зовнішнього середовища та } \\
\text { навпаки, а також } \\
\text { пристосування складових } \\
\text { економічної безпеки. }\end{array}$ \\
\hline
\end{tabular}




\begin{tabular}{|c|c|c|c|}
\hline $\begin{array}{l}I V . \text { Кризовий } \\
0,25 \leq \mathrm{P}<0,5\end{array}$ & $\begin{array}{c}\text { Рівень економічної безпеки є } \\
\text { недостатнім одразу за } \\
\text { декількома компонентами } \\
\text { економічної безпеки. }\end{array}$ & $\begin{array}{c}\text { Трансформаційна } \\
\text { стратегія }\end{array}$ & $\begin{array}{c}\text { Передбачає проведення } \\
\text { змін, які стосуються виду } \\
\text { діяльності та зовнішнього } \\
\text { ринку }\end{array}$ \\
\hline $\begin{array}{c}V . \text { Небезпечний } \\
0 \leq \mathrm{P}<0,25\end{array}$ & $\begin{array}{c}\text { Небезпечному рівню безпеки } \\
\text { відповідає стан, при якому } \\
\text { найвищою є ймовірність } \\
\text { банкрутства та ліквідації } \\
\text { підприємства. }\end{array}$ & $\begin{array}{l}\text { Комплексно- } \\
\text { убезпечуюча } \\
\text { стратегія }\end{array}$ & $\begin{array}{c}\text { Передбачає проведення } \\
\text { заходів посилення всіх } \\
\text { компонент економічної } \\
\text { безпеки підприємства, } \\
\text { значення яких є } \\
\text { недостатнім. }\end{array}$ \\
\hline
\end{tabular}

На думку О.О. Фальченко розроблення стратегії економічної безпеки підприємства слід здійснювати кількома етапами: визначення глобальної цілі підприємства; виявлення резервів підвищення ефективності його можливостей i небезпек зовнішнього середовища; вибір елементів економічної стратегії; визначення локальних цілей; тактичне планування i розроблення альтернативних варіантів тактичних дій; контроль результатів реалізації стратегії [6, с.157].

Для розроблення стратегії забезпечення економічної безпеки підприємств енергетичної галузі необхідно визначити алгоритм формування такої стратегії. У межах алгоритму розроблення стратегії виокремлено основний інструментарій, що використовується для розроблення стратегії забезпечення економічної безпеки підприємств енергетичної галузі (рис.3.) 


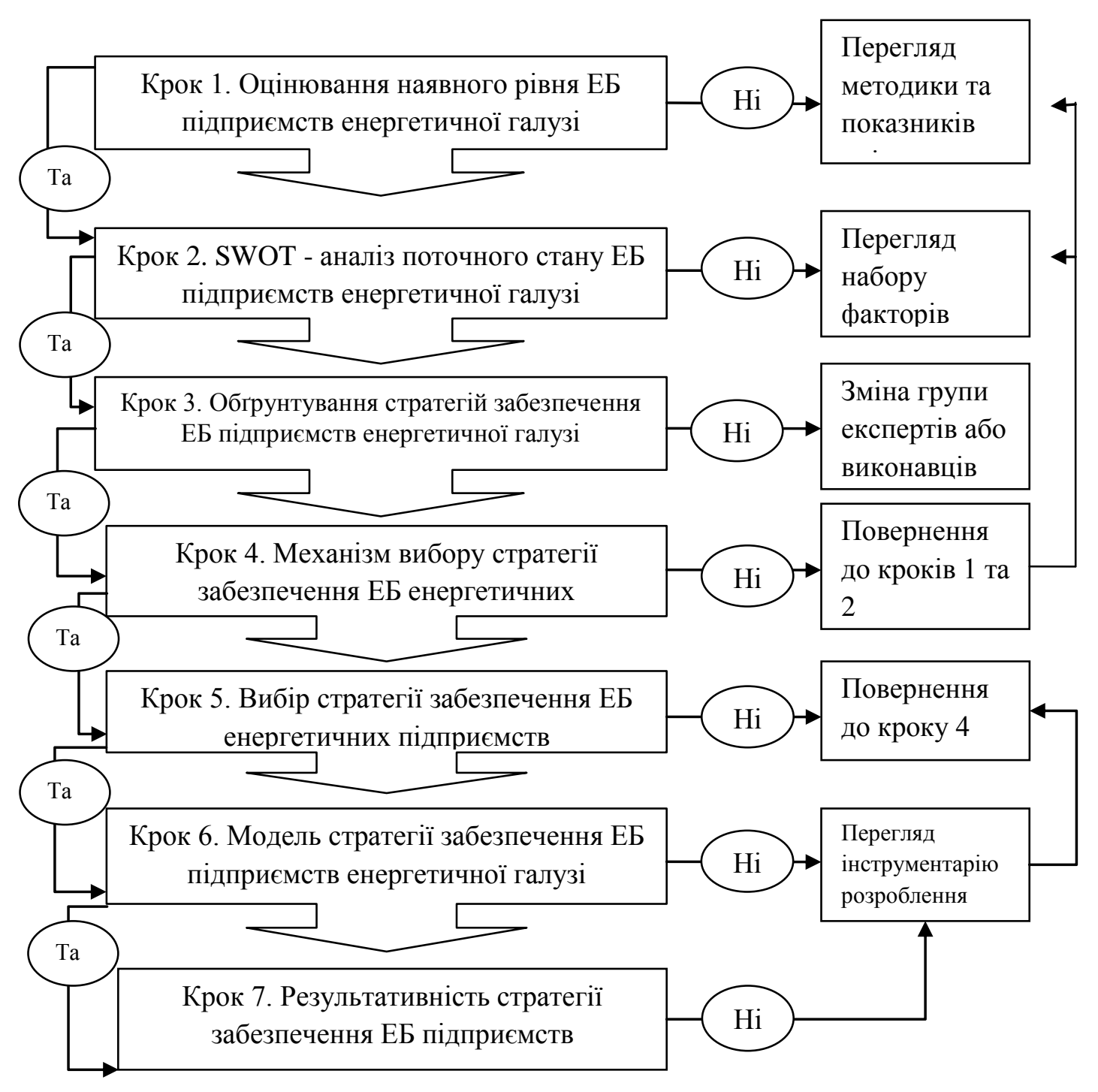

Рис. 3. Алгоритм розроблення стратегії забезпечення економічної безпеки підприємств енергетичної галузі

Варто зазначити, що кожне енергетичне підприємство має свої особливості, внаслідок чого неможливо запропонувати універсальний алгоритм розроблення стратегії забезпечення економічної безпеки підприємств енергетичної галузі, тому базовими при розробленні стратегій забезпечення економічної безпеки мають бути наступні положення:

- існування обмежень щодо розроблення та реалізації стратегії забезпечення економічної безпеки підприємства, що зумовлені рівнем економічної безпеки підприємства, проявами зовнішнього середовища;

- адекватність стратегії забезпечення економічної безпеки підприємства економічній ситуації в країні;

- відповідність стратегії забезпечення економічної безпеки загальній стратегії безпеки країни; 
- ключові елементи стратегії забезпечення економічної безпеки підприємства повинні випливати із специфіки й напрямів діяльності конкретного енергетичного підприємства;

- багатоваріантність стратегій, альтернатива вибору.

Висновки. Таким чином, за результатами дослідження було проаналізовано теоретичні підходи до стратегії забезпечення економічної безпеки підприємства, виокремлено основні етапи процесу розроблення та реалізації стратегії забезпечення економічної безпеки енергетичного підприємства, визначено алгоритм та інструментарій формування такої стратегії.

Наукова новизна отриманих результатів полягає в удосконаленні підходу до розроблення стратегії забезпечення економічної безпеки енергетичних підприємств, який, на відміну від існуючих, враховує рівень економічної безпеки підприємств, що надасть можливість сформувати комплекс рекомендацій по вибору стратегії забезпечення економічної безпеки з урахуванням економічного стану підприємства.

Напрями реалізації даних рекомендацій можуть стати предметом подальших наукових досліджень. Результати дослідження можуть бути використані вітчизняними енергетичними підприємствами під час процесу розроблення та вибору стратегії забезпечення економічної безпеки.

\section{Лiтература :}

1. Васильців Т. Г. Фінансово-економічна безпека підприємств України: стратегія та механізми забезпечення : [монографія] / Васильців Т. Г., Волошин В. І., Бойкевич О. Р., Каркавчук В. В., [за ред. Т.Г. Васильціва]. - Львів: Арал, 2012. - 386 с.

2. Іванюта Т. М. Економічна безпека підприємства : навч. посіб. / Т. М. Іванюта, А. О. Заїчковський. - К. : Центр учбової літератури, 2009. - 256 с.

3. Кравчук П. Я. Формування системи корпоративної безпеки : дис... канд. екон. наук: 08.06.01 «Економіка, організація і управління підприємствами» / Павло Ярославович Кравчук; [Терноп. держ. екон. ун-т]. - Тернопіль, 2006. - 232 с.

4. Шершньова 3. Є. Стратегічне управління : навч. посіб / 3. Є. Шершньова, С. В.Оборська. - K. : KHEУ, 1999. - 384 c. 197.

5. Томпсон А. А. Стратегический менеджмент. Искусство разработки и реализации стратегии: учеб. для вузов. / А. А. Томпсон, А. Дж. Стрикленд; пер. с англ. - М. : Банки и биржи, ЮНИТИ, 1998. -576 с.

6. Фальченко О. О.Стратегія забезпечення економічної безпеки підприємств/ О. О. Фальченко, Ю. С. Глушач // Вісник Національного технічного університету "ХПІ". Сер. : Технічний прогрес та ефективність виробництва. - 2013. - № 66. - С. 157-160. 